\title{
Finance and R\&D Investment: A Panel Study of Italian Manufacturing
} Firms

\author{
Marianna Succurro ${ }^{1} \&$ Giuseppina Damiana Costanzo ${ }^{2}$ \\ ${ }^{1}$ Department of Economics, Statistics and Finance, University of Calabria, Rende, Italy \\ ${ }^{2}$ Department of Business and Juridical Sciences, University of Calabria, Rende, Italy \\ Correspondence: Marianna Succurro, Department of Economics, Statistics and Finance, University of Calabria, \\ Ponte Pietro Bucci-Cubo 0/C, 87036 Arcavacata di Rende (CS), Italy. Tel. 39-0984-492-445. E-mail: \\ m.succurro@unical.it
}

Received: May 5, 2016

Accepted: May 26, 2016

Online Published: July 25, 2016

doi:10.5539/ijef.v8n8p95

URL: http://dx.doi.org/10.5539/ijef.v8n8p95

\begin{abstract}
The purpose of this study is to examine the role of different sources of finance on R\&D investment decisions in Italian manufacturing firms. Accounting data, taken from the Aida database, are collected over the 2006-2013 years. The empirical evidence shows that the availability of external financing primarily affects the decision to engage in $R \& D$ activity rather than $R \& D$ intensity. Internal cash flow, on the contrary, does affect both the likelihood of whether firms will undertake any R\&D and the size of R\&D spending. This impact is strongly significant for financially weaker firms, SMEs and high-tech firms. Due to greater asymmetric information problems, small innovative firms mainly rely on cash-flow to finance innovative projects. Since bank loans and other forms of debt are not well suited for R\&D-intensive activities, our study would contribute to the debate whether it might be socially desirable to incentivize alternative small business financing options, still limited in Italy.
\end{abstract}

Keywords: finance, innovation, $R \& D$, Heckman selection, panel data

\section{Introduction}

It is widely known that innovation is a fundamental driver of productivity and economic growth. It is also widely known that research and development $(R \& D)$ expenditure is difficult to finance in a freely competitive market place (Hall \& Lerner, 2010). As it has been argued in some of the earliest studies, the source of financing is particularly important for investments in the creation of knowledge (Arrow, 1962; Nelson, 1959). R\&D, indeed, is characterized by high firm-specific investment costs but low collateral value, and the potentially great rewards of innovative activity are subject to equally great technological, strategic and market uncertainty (Encaoua et al., 2000). Both positive externalities and capital market imperfections may lead to financing constraints and hence to sub-optimal investment in R\&D.

From an international comparison, $R \& D$ investment has been identified as an area of relative underperformance in Europe compared to the United States. Looking at OECD data on R\&D investment within Western Europe, we can see that the laggards in R\&D expenditure as percentage of GDP are Italy (1.27), Spain (1.3) and Portugal (1.5). The Italian gross domestic expenditure on R\&D is even lower than the EU28 average value (1.98) (OECD Science, Technology and Industry Outlook, 2014).

It would be useful to better understand the causes for this low investment rate in order to adopt effective R\&D policies and managerial strategies. In an international context, where investments in innovation are both at the core of firms' competitiveness strategies and on the top of governments' growth policies, a better understanding of the role of innovation financing is crucial. This study contributes to this brand of literature by providing evidence on the impact of finance on R\&D expenditure for a large sample of Italian manufacturing firms over the 2006-2013 years. We enlarge the literature on funding R\&D by explicitly analyzing the effect of both internal and external finance on R\&D decision making (the decision to invest) and R\&D intensity (given the decision to invest, how much to invest). Being Italy a bank-based economy, the two financial channels could play a different role in comparison with other market-based countries or at the two steps of the R\&D decision making process. Where earlier empirical studies examine either internal or external funding separately, we consider both channels 
simultaneously and evaluate their relative impact on firms' innovation input.

Moreover, while previous empirical work focuses either on large listed companies or adopt selection criteria that tend to eliminate financially weaker firms, our analysis includes a sizable sample of firms and aims at quantifying also the impact of firms' characteristics on R\&D spending. We also conduct sub-sample estimates to analyze the differences in the R\&D effects of a number of factors found to be relevant in previous works.

The paper is organized as follows. Section 2 reports the related literature, Section 3 specifies the econometric model, Section 4 illustrates some descriptive statistics, Section 5 shows the empirical findings, Section 6 concludes.

\section{Literature Review}

Both theoretical and empirical studies focus on the relationship between finance and innovation investment and indicate several reasons why raising funds externally would be more costly for innovation than for other types of investment (EIB, 2009; Hall \& Lerner, 2010).

It is well known that debt markets provide resources at a higher cost, demand a fair amount of assets as collateral, and require complex contracts (Berger \& Udell, 1998; Berger \& Udell, 2002; Carpenter \& Petersen, 2002a). All these elements are exacerbated for innovation projects, so an innovative firm would desire to avoid them when sufficient internally generated funds are available as alternative financing channel.

In other words, given that access to external funding of an innovative firm depends upon a greater presence of asymmetric information problems, it is to be expected that firms, in making their investments, turn first to internal funding and only subsequently to a more expensive external finance (Czarnitzi \& Hottenrott, 2011; Ughetto, 2008; Bougheas et al., 2003; Hall, 2002; Hall, 1990). According to Myers (1984) and Myers and Majluf (1984), indeed, there would be a hierarchy in the use of funds, which is based on information asymmetry. Whenever possible, R\&D expenditure should be covered by internally generated funds, which are not affected by adverse selection problems. If these were not enough, that is if $\mathrm{R} \& \mathrm{D}$ opportunities require more finance, debt would be the next option.

With respect to internal finance, several studies document the importance of cash-flow for R\&D expenditure or explicitly focus on firms' investment sensitivity to cash flow (Hall, 1992; Himmelberg \& Petersen, 1994; Giudici \& Paleari, 2000; Bloch, 2005; Ughetto, 2007; Magri, 2009; Brown et al., 2009; Czarnitzi \& Hottenrott, 2011).

With reference to external funding, different potential sources of financing may exist including both public and private channels. Which of these is appropriate to a specific case depends on a number of factors like the size of the company, the stage of development of the project, the amount of money required, etc. (European Communities, 2002). The choice of debt or equity financing depends on a number of factors and its impact on innovation can differ across countries. However, although recent studies highlight that equity finance has several advantages over debt for financing $R \& D$, debt finance is the most significant source of finance in the majority of countries. New equity finance accounts for only a very small part of total corporate sector financing and this is particularly true for Italy where, because of the underdevelopment of stock and bond markets, debt finance is the main source of external finance. This is also confirmed in the last EU-Efige Survey (Altomonte \& Aquilante 2012).

Several studies highlight the important role of bank loans as external funding of innovative activity. This financial channel is relevant in Italy where the banking system plays a pivotal role in providing financing for businesses (Succurro, 2014; Bugamelli et al., 2012; Giannetti, 2012; Minetti \& Zhu, 2011; Benfratello et al., 2008).

A second group of empirical works show the importance of trade credit as external source of finance (Petersen \& Rajan, 1997; Nilsen, 2002; Danielson \& Scott, 2004; Guariglia \& Mateut, 2006; Love et al., 2007; Ogawa et al., 2013). In Italy, the weight of trade credit has been traditionally important (De Blasio, 2005; Marotta, 2005; De Socio, 2010; Agostino \& Trivieri, 2013). Data used in this paper and described afterwards, indicate that trade credit accounts on average for $24.9 \%$ of firms' total liabilities.

Finally, Venture Capital (VC) and, in general, private equity have been extensively studied in recent years since they should provide external finance to firms which are normally excluded from credit market (Hall, 2010). Economic theory highlights the role played by venture capitalists in reducing asymmetric information by intensively screening firms before providing capital and monitoring them afterwards. The presence of specialized investors would add value to the firm, which may materialize in different ways. However, venture capital, which most analysts see as the best form of finance especially for high-tech firms, is substantially less developed in Italy than in other countries as the UK, Switzerland, the US and Canada (Bottazzi et al., 2008; Bottazzi \& Da 
Rin 2002). The data provided by AIFI (Italian Private Equity and Venture Capital Association) highlight that in the Italian market venture capital plays a negligible role. Indeed, Italian VC-investments account for a $0.003 \%$ of the GDP in 2010, compared to a EU-15 average of $0.029 \%$.

In brief, while $\mathrm{VC}$ plays a rather small role in the external financing of Italian innovative firms, bank loans, other forms of debt and trade credit constitute the main sources of external finance. Note that, with some exceptions (Brown \& Petersen, 2009; Cleary et al., 2007), previous studies mainly examine the investment cash-flow relationship or focus on the impact of either internal or external funding on innovation. However, excluding measures of external or internal finance from regressions can lead to biased estimates because external and internal channels are not mutually independent and it is reasonable to assume that, in making investments, firms take account of all the sources of funding. We expect that the way companies are financed may influence their decision to invest, their level of investment and subsequent financial and innovative performances.

As mentioned above, a number of reasons - essentially related to credit market failures arising from the nature of $R \& D$ as risky and long-term form of investment - have been put forward to motivate the idea that R\&D intensive firms may be less likely to be reliant on external finance. Previous studies, however, mainly focus on market-based economies. Our main objective is to analyze: a) the role of the method of finance in firms' innovation investments in Italy, a bank-based economy; b) the impact of the two financial channels, internal and external funding, at the two important steps of the investment decision making process, that is R\&D decision making (the decision to invest - I step of the analysis) and R\&D intensity (given the decision to invest, how much to invest - II step of the analysis).

Being Italy a bank-based economy, the two financial channels could play a different role in comparison with other market-based countries or at the two steps of the R\&D decision making process. Furthermore, while earlier empirical studies examine either internal or external funding separately, we consider both channels simultaneously and evaluate their relative impact on firms' innovation input.

\section{The Model Specification}

Following Bond and Meghir (1994) and the recent empirical literature on R\&D investment, we apply the Euler equation approach to model $R \& D$ expenditure for Italian manufacturing firms. A more detailed description of the theoretical framework is reported in Supplementary material.

Most of the seminal studies on finance and innovation use a static fixed-effects model which solves the omitted variable problem by controlling for the unobservable individual effect, such as managerial ability, degree of risk aversion, ownership structure, etc. However, additional elements have to be taken into account when analyzing R\&D: the dynamic nature of innovative activity and the endogeneity problem.

There are a number of characteristics of R\&D - like adjustment costs and uncertainty associated with the output - that suggest this type of investment should be analyzed in a dynamic framework. Several empirical studies usually based on sector studies or case studies-show persistence in firms' innovative behavior by finding that innovators at a given period are more likely to innovate at the next time period (Geroski et al., 1997; Lerner, 1997; Cefis \& Orsenigo, 2001; Cefis, 2003). Thus, it is necessary to explicitly consider R\&D inertia.

With respect to endogeneity, as it is known, fixed effects in panel data model allow us to control for the unobservable individual effect but, because of possible reverse causality, selection bias or omitted variables, the endogeneity problem is still present. The traditional approach to solve the problem is an instrumental variables regression with external instruments and fixed or random effects estimators. An alternative approach uses internal instruments, exploiting panel data structure. In our case, we use a Generalized Method of Moment (GMM) estimator (Arellano \& Bond, 1991; Blundell \& Bond, 1998) treating all financial variables as potentially endogenous.

Thus, taking into account both methodological and theoretical considerations, we estimate the following dynamic Euler model:

$$
\begin{gathered}
R \& D_{i, t}=\beta_{0}+\beta_{1} R \& D_{i, t-1}+\beta_{2}\left(R \& D_{i, t-1}\right)^{2}+\beta_{3} I N T F_{i, t-1}+\beta_{4} E X T F_{i, t}+\beta_{5} \text { Size }_{i, t}+\beta_{6} A g e_{i, t}+\beta_{7} C_{4 i, t}+ \\
\beta_{8} W_{i, t}+\gamma_{t}+u_{i}+\varepsilon_{i, t}
\end{gathered}
$$

where $i$ denotes firms, observed over the 2006-2013 years.

$\gamma_{t}$ denotes time effects,

$u_{i}$ firm effects and

$\varepsilon_{i, t}$ the stochastic residuals. 
The dependent variable $R \& D$ denotes the ratio between firms' $R \& D$ expenditure and total assets. One advantage of this input measure is that its economic value may be taken as homogeneous. Our specification is similar to a number of other dynamic models used for R\&D in previous works (Himmelberg \& Petersen, 1994; Bloch, 2005; Brown \& Petersen, 2009). It includes also a lagged dependent variable and can be properly estimated by the system of equations (GMM-SYS) as in Blundell and Bond (1998). This approach, increasingly used in the more recent works on R\&D, combines the first differenced regression used in GMM-DIFF and Equation (1) in levels, whose instruments are the lagged differences of the endogenous variables.

The variables INTF and EXTF denote firms' internal and external financial resources. As usual in the literature, we use cash-flow as indicator of internal financial resources and measure internal finance (INTF) as the ratio of cash flow to total assets. By external financing we mean funds not generated internally (not self-financing), thus we measure external finance (EXTF) as the ratio of loans, long-term debt and trade credit to total assets (Note 1). Unlike indirect measures of external finance in which aggregate county-level bank deposits proxy for bank loans, our analysis has the advantage of using micro-data on loans and additional external resources reported in the accounts.

We scale the main variables by total assets since it is indicated in previous studies as the appropriate scale variable in R\&D regressions (Bloch, 2005; Brown \& Petersen, 2009).

Note that, like in Bond and Meghir (1994), time-specific and firm-specific effects in the empirical specification also control for the variation of the user cost of capital.

The other explanatory variables include firm-level, industry-level and region-level variables. Specifically:

Size of the firm, measured in terms of annual turnover (Note 2);

Age, measured as the difference between the last available year of data and the year of foundation;

Ownership concentration, computed as the percentage of ownership held by the main shareholder, which takes account of the governance structure of the firm. This variable varies between 0 and 1 (fully concentrated ownership).

$C_{4}$, a traditional structural measure of market concentration based on market shares, has been included to take account of the market power. In general, a $C_{m}$ concentration ratio is defined as the percentage of market share held by the largest $m$ firms in an industry:

$$
C_{m}=\sum_{i=1}^{m} s_{i}
$$

where $s_{i}$ is the market share and $m$ defines the $\mathrm{i}^{\text {th }}$ firm. This study includes the concentration ratio $\mathrm{C}_{4}$ which measures the total market share of the four largest firms in each manufacturing sector included in the analysis and it is comparable from sector to sector.

Finally, our model includes the W matrix which considers relevant regional-level controls. We explicitly investigate whether R\&D investment is also affected by the social characteristics of the community in which the firm operates and by additional environmental variables affecting firms' behavior. There is a growing number of studies investigating the role of social capital in households' and firms' behavior or the externalities generated by environmental variables on firms' performances (La Porta et al., 1997; Ichino \& Maggi, 2000; Knack \& Zack 2001; Guiso et al., 2004, Benfratello et al., 2008). Following this branch of literature, we expect that a higher level of social cohesion and, in general, a favorable environment, may lead to a higher level of long-term investments, like R\&D projects. Thus, we augment our firm-level data with the following environmental variables:

$T K$, a measure of technological capital, computed as the 3-year stock of patents per 1,000 population; $H K$, a measure of human capital, calculated as the number of people with a scientific degree per 1,000 residents aged 20-29; Firm Density, an indicator of competition but also of technological externality among firms, computed as the average number of firms per 1,000 inhabitants; GDP, per capita gross domestic product; Infr, a proxy of public infrastructures, computed as kilometers of highway network in each region (per 1,000 square kilometers).

Note that we drop observations with missing values in the explanatory variables and, in order to correct for significant outliers, we eliminate observations in the top and bottom 5 percentiles.

\section{Data and Descriptive Statistics}

This study uses firm-level financial data taken from the Aida database published by Bureau van Dijk, 
supplemented by regional-level data taken from the Istat database. Our dataset includes all the active firms in the Italian manufacturing sectors over the 2006-2013 years. The manufacturing sectors are defined to include firms in the NACE Rev.2 primary codes 10-32.

Data on R\&D expenditure have been drawn from the notes appended to balance sheet accounts by means of an optical reading procedure supplied by Bureau van Dijk (Note 3). Data are collected over the 2006-2013 period, but the panel is unbalanced since each firm in the dataset has different numbers of observations. On average, there are $\mathrm{n}=45114$ firms and $\mathrm{T}-\mathrm{bar}=5.20$ time periods.

The percentage of firms undertaking $R \& D$ expenditure (that is with positive $R \& D$ spending) is found to be around $47 \%$ of all the manufacturing firms. A similar percentage (44.98\%) is found in the last EU-Efige Survey (Altomonte \& Aquilante, 2012).

Table 1 reports the distribution of the Italian manufacturing firms included in our analysis by sectors and geographical location, by distinguishing between $R \& D$ performing and non-R\&D-performing firms.

Looking at the distribution of $R \& D$ performing firms, the highest percent values are in the sectors of fabricated metal products $(18.20 \%)$, machinery and equipment $(15.32 \%)$, food products $(8.24 \%)$, other non-metallic mineral products $(6.14 \%)$, rubber and plastic products $(5.85 \%)$, textiles $(4.58 \%)$, electrical equipment $(4.46 \%)$ and furniture $(4.32 \%)$.

The percentage of non-R\&D-performing firms is relatively higher in low-tech or medium-low-tech sectors like the manufacture of food products, textiles, leather and related products, wood, other non-metallic mineral products and basic metals.

With reference to the geographical location, the manufacturing firms are heavily concentrated in Northern Italy, the most developed and productive area of the country, where the percentage of firms undertaking $R \& D$ activity is clearly higher than in the rest of the country.

Table 1. Distribution of firms by sectors (NACE Rev.2 primary codes) and geographic location, \% values

\begin{tabular}{|c|c|c|c|}
\hline & & \multicolumn{2}{|c|}{ Non-R\&D-performing firms R\&D performing firms } \\
\hline 10 & Manufacture of food products & 12.56 & 8.24 \\
\hline 11 & Manufacture of beverages & 1.67 & 1.39 \\
\hline 12 & Manufacture of tobacco products & 0.11 & 0.05 \\
\hline 13 & Manufacture of textiles & 5.26 & 4.58 \\
\hline 14 & Manufacture of wearing apparel & 3.98 & 4.07 \\
\hline 15 & Manufacture of leather and related products & 4.83 & 3.75 \\
\hline 16 & $\begin{array}{l}\text { Manufacture of wood and of products of wood and cork, except furniture; } \\
\text { manufacture of articles of straw and plaiting materials }\end{array}$ & 3.52 & 2.80 \\
\hline 17 & Manufacture of paper and paper products & 2.67 & 2.52 \\
\hline 18 & Printing and reproduction of recorded media & 1.78 & 2.27 \\
\hline 19 & Manufacture of coke and refined petroleum products & 0.45 & 0.40 \\
\hline 20 & Manufacture of chemicals and chemical products & 3.85 & 3.97 \\
\hline 21 & Manufacture of basic pharmaceutical products and pharmaceutical preparations & 0.39 & 0.65 \\
\hline 22 & Manufacture of rubber and plastic products & 5.64 & 5.85 \\
\hline 23 & Manufacture of other non-metallic mineral products & 8.44 & 6.14 \\
\hline 24 & Manufacture of basic metals & 4.03 & 2.81 \\
\hline 25 & Manufacture of fabricated metal products, except machinery and equipment & 17.18 & 18.20 \\
\hline 26 & Manufacture of computer, electronic and optical products & 2.00 & 2.83 \\
\hline 27 & Manufacture of electrical equipment & 2.92 & 4.46 \\
\hline 28 & Manufacture of machinery and equipment nec & 11.48 & 15.32 \\
\hline 29 & Manufacture of motor vehicles, trailers and semi-trailers & 1.41 & 1.60 \\
\hline 30 & Manufacture of other transport equipment & 1.23 & 1.13 \\
\hline 31 & Manufacture of furniture & 2.88 & 4.32 \\
\hline \multirow[t]{6}{*}{32} & Other manufacturing & 1.74 & 2.55 \\
\hline & TOTAL & 100.00 & 100.00 \\
\hline & North & 67.21 & 72.23 \\
\hline & Centre & 20.19 & 18.07 \\
\hline & South and Islands & 12.6 & 9.69 \\
\hline & TOTAL & 100.00 & 100.00 \\
\hline
\end{tabular}

Source: Based on Aida data. 
At an aggregate level, more than $46.47 \%$ of total R\&D expenditure is accounted for by large companies, $22.41 \%$ by medium-sized companies and $21.07 \%$ by small firms (Table 2). The firm size is measured in terms of annual turnover, which allows to split the sample on the basis of the threshold values reported in the Commission Recommendation 96/280/EC (updated in 2003/361/EC of May 6, 2003): small firms ( $€ 2 \mathrm{mln}<$ turnover $<€ 10$ $\mathrm{mln}$ ); medium-sized firms ( $€ 10 \mathrm{mln}<$ turnover $<€ 50 \mathrm{mln}$ ); large firms (turnover $>€ 50 \mathrm{mln}$ ). Data show a quite similar composition of our sample and Efige sample. Small firms represent the most numerous group, followed by medium sized firms and, with less than $5 \%$, by large firms. In the rest of the paper we carry out our analysis by considering small and medium enterprises (SMEs) together.

Table 2. Distribution of firms with R\&D activity by size class (average values, 2006-2013)

\begin{tabular}{lcc}
\hline & Our dataset & EU-Efige Survey Sample \\
\hline Small & $75.76 \%$ & $77.81 \%$ \\
Medium & $20.54 \%$ & $18.19 \%$ \\
Large & $3.68 \%$ & $3.99 \%$ \\
\hline & $100 \%$ & $100 \%$ \\
\hline
\end{tabular}

Source: Based on Aida and EU-Efige databases.

Table 3 shows some descriptive statistics for research and development spending to total assets $(R \& D)$, total external financial resources to total assets $(E X T F)$ and cash-flow to total assets (INTF). Data indicate that both external funds and internal funds are, on average, slightly lower among small and medium sized firms. INTF can also take negative values, which is a common proxy for characterizing firms that are in financially distressed situations (Cleary et al., 2007; Brown \& Petersen, 2009). To ensure that all the companies are in normal operations and to avoid classification problems related to possible bankruptcy procedures reported in the Aida database, we restrict the study to positive levels of internal funds, thus we exclude from the study financially distressed firms which represent around 6\% of the sample (6.19\% of large firms; $6.061 \%$ of SMEs).

Among those firms with positive internal finance, instead, we distinguish between financially weak firms and financially strong firms. By financially weak firms we mean firms characterized by low levels of internal funds, that is cash-flow less than the sample-mean value; by financially strong firms we mean firms with relatively higher level of internal funds, that is with cash-flow greater than the sample-mean value. Following this classification scheme, we find $57.83 \%$ of firms in a financially weak situation $(45.43 \%$ of large firms and $58.30 \%$ of SMEs respectively).

Table 3. Main variables and summary statistics (2006-2013, average values)

\begin{tabular}{lccc}
\hline & All Firms & Large & SMEs \\
\hline$R \& D$ & & & 0.0054 \\
Mean & 0.0054 & 0.0061 & 0.0016 \\
Median & 0.0016 & 0.0021 & 0 \\
Min & 0 & 0 & 0.0491 \\
Max & 0.0491 & 0.0491 & 0.4285 \\
EXTF & & & 0.4375 \\
Mean & 0.4286 & 0.4412 & 0 \\
Median & 0.4659 & 0.4611 & 3.5139 \\
Min & 0 & 0 & 0.0549 \\
Max & 3.5139 & 0.9980 & 0.0462 \\
$I N T F$ & & & -0.0593 \\
Mean & 0.0553 & 0.0665 & 0.1914 \\
Median & 0.0467 & 0.0612 & 226039 \\
Min & -0.0593 & -0.0591 & 0.1912 \\
Max & 0.1914 & 8537 & \\
Obs. & 234576 & & 0 \\
\hline
\end{tabular}

Source: Based on Aida Database. 
As a preliminary, we also analyze the correlation between innovation and finance, gauged by the foregoing ratios, separately for large companies and SMEs, and for financially weak and strong firms (Table 4). With the exception of large firms, the correlation coefficient between external finance and R\&D expenditure is generally positive and significant at the $1 \%$ level. The correlation between internal funds and R\&D expenditure varies among the analyzed groups, both in the sign and the level of significance, being significant with a small positive coefficient for SMEs and financially weaker firms. Data would show a significant, although small, negative correlation between external and internal funding. The two channels of finance, indeed, are not expected to be unrelated, as servicing the debt reduces the cash flow for future investments (Hall, 1990; Hall, 2002; Czarnitzi \& Hottenrott, 2011).

Table 4. Correlation between $R \& D$ and financial resources

\begin{tabular}{|c|c|c|c|c|c|c|c|}
\hline \multicolumn{4}{|c|}{ Large firms } & \multicolumn{4}{|c|}{ SMEs } \\
\hline & $R \& D$ & EXTF & INTF & & $R \& D$ & EXTF & INTF \\
\hline$R \& D$ & 1.000 & & & $R \& D$ & 1.000 & & \\
\hline EXTF & 0.0145 & 1.000 & & EXTF & $0.0615 * * *$ & 1.000 & \\
\hline INTF & -0.0043 & $-0.2579 * * *$ & 1.000 & $I N T F$ & $0.0062 * * *$ & $-0.1885^{* * *}$ & 1.000 \\
\hline \multicolumn{4}{|c|}{ Low INTF } & \multicolumn{4}{|c|}{ High INTF } \\
\hline & $R \& D$ & EXTF & INTF & & $R \& D$ & $E X T F$ & INTF \\
\hline$R \& D$ & 1.000 & & & $R \& D$ & 1.000 & & \\
\hline EXTF & $0.0471 * * *$ & 1.000 & & EXTF & $0.0874 * * *$ & 1.000 & \\
\hline INTF & $0.0372 * *$ & $-0.0907 * *$ & 1.000 & $I N T F$ & $-0.0382 *$ & $-0.1858 * * *$ & 1.000 \\
\hline
\end{tabular}

Note. Pairwise correlations significance levels: $* 10 \% ; * * 5 \% ; * * * 1 \%$.

\section{Empirical Results}

\subsection{The Decision to Undertake $R \& D$}

As introduced above, the variable $R \& D$ expenditure over total assets is zero for a non-negligible proportion of the population, and is essentially continuous over positive values. In other words, there is a mass point at zero because many firms find a corner solution optimal and do not invest in R\&D activity. In order to test for the presence of non-random selection bias, we adopt a two-step estimation procedure (Heckman, 1979; Vella \& Verbeek, 1999) comprising a selection equation and an outcome equation, using observations on both R\&D performing firms and other firms. In the first step firms decide whether to engage in R\&D activity or not (selection equation). Given that a firm has decided to invest in R\&D, then the performance equation is estimated. More specifically, the selection equation can be specified as:

$$
R \& D_{0 i}= \begin{cases}1 & \text { if } R \& D_{0 i}^{*}=X_{0 i} \beta_{0}+\varepsilon_{0 i}>0 \\ 0 & \text { if } R \& D_{0 i}^{*}=X_{0 i} \beta_{0}+\varepsilon_{0 i} \leq 0\end{cases}
$$

where $R \& D_{0 i}$ is the observed binary variable taking value 1 if firm $i$ reports positive $R \& D$ expenditures, 0 otherwise.

The R\&D activity equation can be specified as:

$$
R \& D_{i}=R \& D_{i}^{*}=W_{i} \beta_{1}+\varepsilon_{i} \text { if } R \& D_{0 i}=1
$$

where $R \& D_{i}^{*}$ is the unobserved latent variable accounting for firm's innovative effort. $\mathrm{X}_{0 \mathrm{i}}$ and $\mathrm{W}_{\mathrm{i}}$ are sets of variables explaining innovation decision and R\&D activity performance. Assuming that the error terms $\varepsilon_{0 \mathrm{i}}$ and $\varepsilon_{\mathrm{i}}$ are independent and identically distributed drawings from a normal distribution with zero mean, the system of Eq. 2 and 3 can be estimated by maximum likelihood. In the literature, this model is referred to as a Heckman selection model (Heckman, 1979). Note that we estimate the correlation, $\rho$, of the two residuals in equations (2) and (3) and a chi-square test is used to decide if $\rho$ is significantly different from zero. When there is no correlation, the selection equation is not necessary.

Note that, for more robust identification, it is usually recommended that exclusion restrictions be imposed. This requires the selection equation to have at least an exogenous variable that is excluded from the outcome equation (Cameron \& Trivedi 2009). The excluded variable should have a relevant impact on the probability of selection. Thus, we compute the two-step Heckman model with age-squared and Criminality as additional regressors in the selection equation. Criminality, a proxy of social cohesion, is computed at regional level as the number of people 
denounced for crimes per 100,000 inhabitants (source: Istat).

Table 5 reports the regression model with sample selection (Note 4). Explanatory variables are strongly significant in determining the probability of positive R\&D spending. Financial variables, in particular, enter at $1 \%$ level of significance with the expected positive sign. Both internal and external financial resources affect the decision to engage in R\&D activity (hence the difference between zero vs positive values), with a greater impact of external finance. In Italy, a bank-based economy, the access to external debt financing can significantly affect the decision to invest in innovation projects.

The likelihood-ratio test, however, has a p-value of 0.73 , thus the estimated correlation between the errors is not significantly different from zero and the hypothesis that the two parts are independent cannot be rejected.

Specifically, as this test is not significant at the conventional levels, we cannot reject the null hypothesis of absence of correlation between the selection and the outcome process. Hence, the performance equation can be estimated separately. This is what we extensively do in the next paragraph.

Table 5. Heckman selection model - dependent variable: probability $(R \& D>0)$

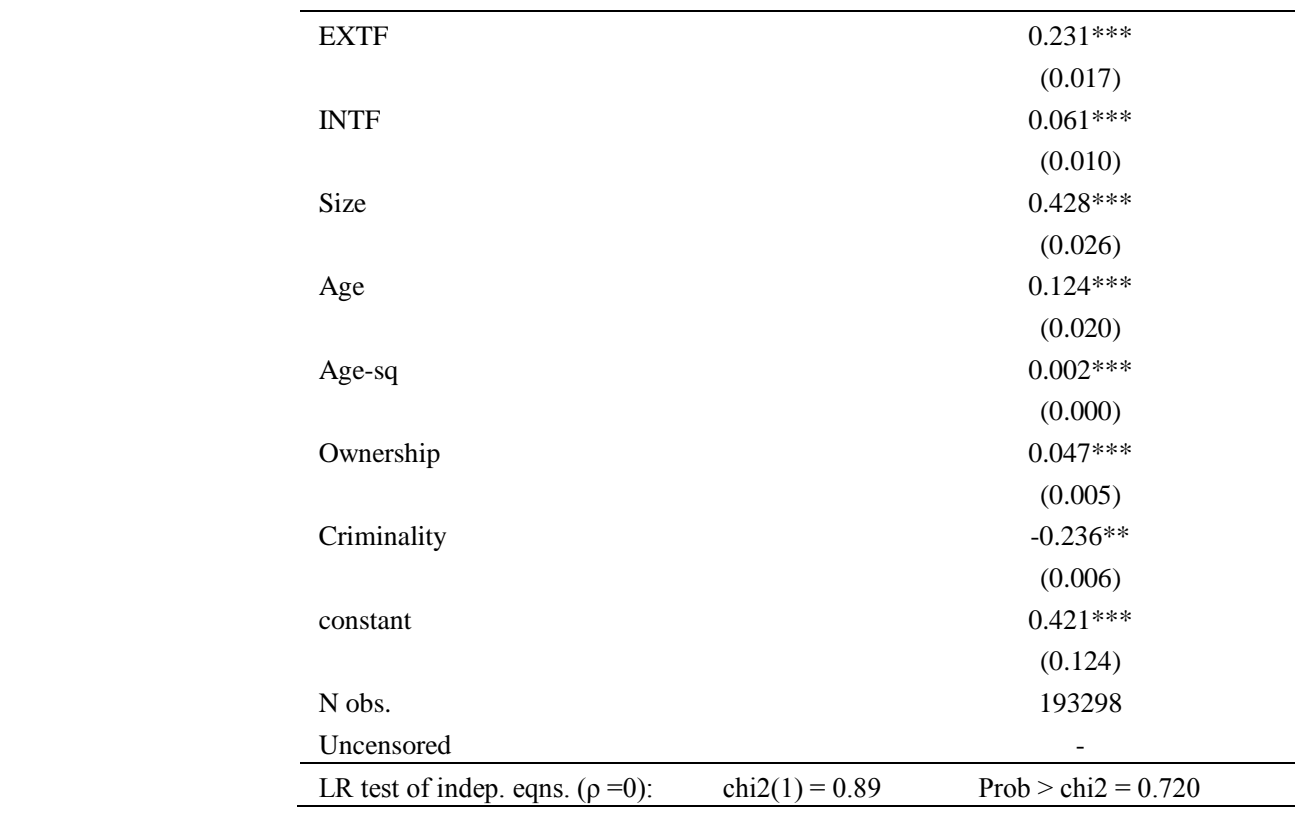

Note. Significance levels: $* 10 \%$; **5\%; ***1\%. Standard errors in parenthesis.

\subsection{The Determinants of $R \& D$ Expenditure}

This section illustrates our empirical findings based on GMM-System estimates of the Euler equation (1). We also report the estimates for different sub-samples of the Italian manufacturing firms.

The results of the tests proposed by Arellano and Bond (1991) are used to detect first- and second-order serial correlation in the residuals. The absence of second-order serial correlation, a necessary condition for the validity of the instruments, is satisfied in our analysis in which we use two lags of the endogenous variables (Note 5). A second specification test is for overidentifying restrictions. Since $p>0.05$, the null hypothesis that the population moment conditions are correct is not rejected, so overidentifying restrictions are valid. Thus, our test statistics suggest a proper specification of the model.

As it is reported in Table 6, Table 7 and Table 8, and consistently with the theoretical framework, R\&D is highly persistent since the coefficient of the lagged dependent variable is always significant and positive for all the regressions. Also the lagged R\&D squared enters significantly with the expected sign and value. The term R\&Dt-1 squared reflects the assumed quadratic form of the adjustment cost function. Under this assumption, the coefficient on the squared R\&Dt-1 is expected to be negative and less than minus one.

Although previous evidence on the impact of finance on innovation is mixed, the majority of works aimed at evaluating the impact of a single financial channel on innovation usually find a positive impact of external finance (bank loans or other debt contract) or internal finance (usually cash-flow) on innovation. Our empirical 
findings confirm the importance of cash-flow as essential determinant of R\&D expenditure, as INTF enters with positive sign at $1 \%$ level of significance (Table 6, reg.1). The availability of bank loans and other forms of debt would have a positive impact on R\&D spending, but EXTF enters at low level of significance and its impact on R\&D investment strongly depends on some characteristics of the firms, like the financial status and size of the company.

Indeed, when we split the sample into financially weak firms and financially strong firms, which represent $57.8 \%$ and $42.1 \%$ of the sample respectively, we find that the impact of external funding on R\&D varies according to the financial health of the company. Similarly to what has been found in other analyses (Giannetti, 2012), bank loans and other forms of debt would play a more important role - both in coefficient and level of significance - in financing investments for financially weak firms, expected to be more reliant on external financing, while their impact is rather limited for strong firms.

Internal finance is a strong determinant of R\&D expenditure of financially weak firms (Table 6, reg.2), which represent the widest group of our sample. Note that the econometric results on the sign of internal finance are consistent with the theoretical model adopted here: it enters significantly with positive sign for weak firms, it enters with negative sign for strong firms. As argued by Bond and Meghir (1994), the negative sign on lagged internal finance (Table 6, reg.3), based on the assumption that firms can raise as many funds as they desire at a given cost, mainly reflects the marginal revenue product of capital for these firms. Summarizing, R\&D expenditure would increase with internal funds if they are low and decreases if they are sufficiently high.

These results are somehow consistent with the differences obtained by splitting the sample into large firms and SMEs, which are usually more sensitive to financial factors than large ones. Estimates are reported on Table 7.

While we get no significant effect of external funding on large firms' R\&D investment, we find that the access to external finance is significant in explaining small firms' innovative activity. This result is somehow in line with studies (Benfratello et al. 2008 among others) indicating that an easier access to external finance would have a positive impact on innovation, especially on small firms' R\&D investment.

Empirical findings also confirm the positive and significant relationship between $R \& D$ expenditure and internal funds for SMEs. For this group of firms, the main source of innovation financing is internal cash flow and the result might be interpreted as if a positive liquidity effect of internal finance compensated for the negative effect of marginal profitability implied by the model specification (Bond \& Meghir, 1994).

Other studies have found similar findings. Brown and Petersen (2011), for example, show that firms most likely to face financing frictions rely heavily on internal finance to smooth $R \& D$ spending, firms less likely to face financing frictions appear to smooth R\&D without the use of cash reserves. Brown et al. (2009) and Himmelberg and Petersen (1994) highlight that large firms are unlike to face significant finance constraints, as they may have better access to external finance and generate cash-flow in excess of investment needs. Consistently with these studies, we find that the two sources of finance are not significant determinants of large firms' $R \& D$ expenditure.

With reference to additional control variables, previous empirical findings are ambiguous and sometimes contradictory. Differences in results are observed in particular with respect to firm size and age.

Several arguments - like economies of scale in R\&D technology, higher returns from R\&D investment and greater ability to secure funding - have been put forward to support the hypothesis that R\&D increases with firm size. Therefore, one should expect a positive effect of size on R\&D since larger firms usually face less severe financing constraints given their lower difficulty in providing collateral. However, the explosive growth of the knowledge economy has been accompanied by a large number of innovative start-ups. This evidence relates to small firms' greater propensity for innovation (Pederzoli et al., 2013; Arora et al., 2001). Previous findings on the relationship between age and R\&D are ambiguous as well. Some authors find lower R\&D investment by younger firms, owing to the financial constraints (Savignac, 2008; Schneider \& Veugelers, 2010), while some recent studies have found that young firms tend to be more innovative, to create new technologies, products and markets (Baumol, 2002).

Our own general estimates indicate that firm size has a positive impact on $R \& D$ expenditure, therefore supporting the main hypothesis that firm innovative activity is positively correlated with firm dimensions. Also the empirical findings on firm age indicate its positive impact on R\&D for all the considered sub-samples, even if with different level of significance. The results suggest that the Italian established firms invest relatively more in $R \& D$ than younger firms, perhaps because of learning economies also attributable to persistence in innovative activity.

The empirical evidence on ownership concentration is in line with the overall results. Indeed, the variable 
Ownership enters significantly with positive sign in all the regressions, indicating a positive impact of ownership concentration on R\&D spending. Ownership concentration would foster the innovative activity by presumably aligning the incentives between management and shareholders in long term investment decisions, like R\&D projects. Thus, it would allow to reduce agency conflicts and improve innovative capacity.

With the exception of large firms, the coefficient of the sector concentration rate, on the contrary, is not significant. The empirical findings on the additional control variables, not reported here but available on request, indicate that they are almost all significant, at $5 \%$ or $1 \%$ level, with the expected sign.

Table 6. GMM System estimation results - all firms, weak and strong firms (2006-2013)

\begin{tabular}{|c|c|c|c|}
\hline \multicolumn{4}{|c|}{ Dependent variable: $R \& D_{i, t}$} \\
\hline & All Firms & $\begin{array}{c}\text { Financially Weak Firms } \\
\text { (Low INTF) }\end{array}$ & $\begin{array}{c}\text { Financially Strong Firms } \\
\text { (High INTF) }\end{array}$ \\
\hline & $(1)$ & $(2)$ & (3) \\
\hline \multirow[t]{2}{*}{$\mathrm{R} \& \mathrm{D}_{\mathrm{i}, \mathrm{t}-1}$} & $0.867 * * *$ & $0.813 * * *$ & $0.796 * * *$ \\
\hline & $(0.036)$ & $(0.010)$ & $(0.012)$ \\
\hline \multirow[t]{2}{*}{$\left(R \& D_{i, t-1}\right)^{2}$} & $-1.936^{* * *}$ & $-1.483^{* * *}$ & $-1.034 * *$ \\
\hline & $(0.804)$ & $(0.846)$ & $(0.898)$ \\
\hline \multirow[t]{2}{*}{$\mathrm{INTF}_{\mathrm{i},-1-1}$} & $0.098 * * *$ & $0.122 * * *$ & $-0.080 * *$ \\
\hline & $(0.009)$ & $(0.028)$ & $(0.037)$ \\
\hline \multirow[t]{2}{*}{ EXTF $_{\mathrm{i}, \mathrm{t}}$} & $0.195^{*}$ & $0.223 * * *$ & $0.092 *$ \\
\hline & $(0.040)$ & $(0.057)$ & $(0.049)$ \\
\hline \multirow[t]{2}{*}{ Size $_{i, t}$} & $0.265^{* *}$ & $0.246^{* *}$ & $0.363^{*}$ \\
\hline & $(0.037)$ & $(0.045)$ & $(0.054)$ \\
\hline \multirow[t]{2}{*}{$\operatorname{Age}_{\mathrm{i}, \mathrm{t}}$} & $0.019 * * *$ & $0.031 *$ & $0.132 * *$ \\
\hline & $(0.052)$ & $(0.074)$ & $(0.077)$ \\
\hline \multirow[t]{2}{*}{ Ownership $_{\mathrm{i}, \mathrm{t}}$} & $0.127^{* *}$ & $0.109^{*}$ & $0.201 * *$ \\
\hline & $(0.032)$ & $(0.023)$ & $(0.009)$ \\
\hline \multirow[t]{2}{*}{$\mathrm{C}_{4}$} & -0.000 & -0.045 & 0.092 \\
\hline & $(0.037)$ & $(0.054)$ & $(0.066)$ \\
\hline Regional controls & included & included & included \\
\hline \multirow[t]{2}{*}{ constant } & -0.0060 & $0.002 * *$ & $0.002 *$ \\
\hline & $(0.001)$ & $(0.003)$ & $(0.001)$ \\
\hline Wald test & $22908.75^{* * *}$ & $10651.37 * * *$ & $7281.02 * * *$ \\
\hline Sargan test ( $p$ value) & 0.102 & 0.146 & 0.120 \\
\hline $\operatorname{AR}(1)(p$ value $)$ & 0.000 & 0.000 & 0.000 \\
\hline AR (2) ( $p$ value) & 0.763 & 0.324 & 0.468 \\
\hline $\mathrm{N}$ firms & 37810 & 25454 & 19063 \\
\hline $\mathrm{N}$ obs. & 176979 & 84318 & 56769 \\
\hline $\mathrm{R}^{2}$ & 0.16 & 0.17 & 0.13 \\
\hline
\end{tabular}

Note. Significance levels: *10\%; **5\%; ***1\%.

Table 7. GMM System estimation results, large firms and SMEs (2006-2013)

\begin{tabular}{lcc}
\hline Dependent variable: $R \& D_{i, t}$ & & SMEs \\
\hline & LARGE Firms & $(2)$ \\
\hline$R \& D_{i, t-1}$ & $0.793^{* * * *}$ & $0.832^{* * *}$ \\
& $(0.031)$ & $(0.017)$ \\
$\left(R \& D_{i, t-1}\right)^{2}$ & $-0.126^{* *}$ & $-1.362^{* * *}$ \\
& $(0.879)$ & $(0.846)$ \\
$\operatorname{INTF}_{\mathrm{i}, t-1}$ & -0.148 & $0.201^{* * *}$ \\
& $(0.093)$ & $(0.027)$ \\
$\operatorname{EXTF}_{\mathrm{i}, \mathrm{t}}$ & 0.126 & $0.084^{* * *}$ \\
& $(0.102)$ & $(0.042)$ \\
\hline
\end{tabular}




\begin{tabular}{lcc}
\hline Size $_{\mathrm{i}, \mathrm{t}}$ & 0.056 & $0.324^{* * *}$ \\
& $(0.138)$ & $(0.039)$ \\
Age $_{\mathrm{i}, \mathrm{t}}$ & 0.178 & $0.133^{* *}$ \\
& $(0.185)$ & $(0.054)$ \\
Ownership $_{\mathrm{i}, \mathrm{t}}$ & $0.123^{* *}$ & $0.098^{*}$ \\
& $(0.098)$ & $(0.087)$ \\
$\mathrm{C}_{4}$ & $0.284 *$ & -0.024 \\
& $(0.151)$ & $(0.039)$ \\
Regional controls & included & included \\
constant & $-0.439 * *$ & $-0.012^{*}$ \\
& $(0.210)$ & $(0.001)$ \\
\hline Wald test & $1482.61 * * *$ & $18036.48 * * *$ \\
Sargan test $(p$ value $)$ & 0.478 & 0.112 \\
AR $(1)(p$ value $)$ & 0.000 & 0.000 \\
AR $(2)(p$ value $)$ & 0.334 & 0.458 \\
$\mathrm{~N}$ firms & 1477 & 36759 \\
$\mathrm{~N}$ obs. & 6262 & 168592 \\
$\mathrm{R}^{2}$ & 0.16 & 0.15 \\
\hline
\end{tabular}

Note. Significance levels: *10\%; **5\%; ***1\%.

Finally, we focus on the relationship between finance and innovation in high-tech sectors, identified following Archibugi (2001). Table 8 reports our main empirical findings. Once again, we obtain different results referring to large companies and SMEs operating in high-tech sectors, but the main evidence indicates the pivotal role played by internal cash-flow in financing R\&D.

Large high-tech firms with monopolistic power can rely more on profits as a source of finance, thus we expect they can take advantage of growth opportunities with no need to access external funds. Indeed, we find no effect of finance on $R \& D$ for large innovative firms.

It is interesting to note that also for the sub-sample of SMEs in high-tech sectors, external finance is not significant in explaining R\&D expenditure. Due to greater asymmetric information problems, SMEs mainly rely on internal finance which, indeed, enters at $1 \%$ level of significance. An extensive literature has observed that innovative firms face more severe external financial constraints (Hall \& Lerner, 2010; Brown et al., 2009; Carpenter \& Petersen, 2002b; Hall, 2002; Ughetto, 2008; Hall, 2002; Himmelberg \& Petersen, 1994). Whenever possible, that is for sufficient levels of cash-flow, R\&D expenditure is covered by internally generated funds, which are not affected by adverse selection problems.

In brief, the econometric results would highlight the negligible role of external resources in explaining R\&D activity in high-tech sectors, where innovative firms mainly rely on internal resources to finance innovative projects.

With reference to additional firm-level controls, size is found to be a negative determinant of innovation among innovative SMEs, likely suggesting a greater propensity for innovation among start-ups. The last evidence would be consistent with more recent empirical works on start-ups. Age, instead, enters significantly with positive sign in all the regressions confirming the importance of learning economies for $\mathrm{R} \& \mathrm{D}$ projects in the high-tech sectors, given the higher coefficient associated to this variable in comparison with previous regressions. Ownership concentration enters with positive sign and is significant only for large innovative firms, while the results suggest that the incentive to innovate is greater among both large firms and SMEs, provided they can also exert some degree of market power. The coefficient of the industry concentration rate, indeed, is positive and significant for both groups. 
Table 8. GMM System estimation results, high-tech firms (2006-2013)

\begin{tabular}{|c|c|c|c|}
\hline \multicolumn{4}{|c|}{ Dependent variable: $R \& D_{i, t}$} \\
\hline & All high-tech Firms & LARGE innovative Firms & Small and medium innovative Firms \\
\hline & $(1)$ & $(2)$ & (3) \\
\hline \multirow[t]{2}{*}{$\mathrm{R} \& \mathrm{D}_{\mathrm{i}, \mathrm{t}-\mathrm{1}}$} & $0.812 * * *$ & $0.861 * * *$ & $0.809 * * *$ \\
\hline & $(0.012)$ & $(0.142)$ & $(0.063)$ \\
\hline \multirow[t]{2}{*}{$\left(\mathrm{R} \& \mathrm{D}_{\mathrm{i}, \mathrm{t}-1}\right)^{2}$} & $-1.864 * * *$ & $-1.045^{* *}$ & $-2.291 * * *$ \\
\hline & $(0.987)$ & $(0.786)$ & $(0.934)$ \\
\hline \multirow[t]{2}{*}{ INTF $_{\mathrm{i}, \mathrm{t}-1}$} & $0.006^{* *}$ & -0.069 & $0.017 * * *$ \\
\hline & $(0.002)$ & $(0.106)$ & $(0.005)$ \\
\hline \multirow[t]{2}{*}{$\mathrm{EXTF}_{\mathrm{i}, \mathrm{t}}$} & 0.049 & 0.156 & 0.087 \\
\hline & $(0.067)$ & $(0.180)$ & $(0.001)$ \\
\hline \multirow[t]{2}{*}{ Size $_{i, t}$} & $-0.171^{* *}$ & 0.248 & $-0.218^{* * *}$ \\
\hline & $(0.063)$ & $(0.200)$ & $(0.064)$ \\
\hline \multirow[t]{2}{*}{ Age $_{i, t}$} & $0.221 * *$ & $0.032 * *$ & $0.235^{* *}$ \\
\hline & $(0.094)$ & $(0.252)$ & $(0.093)$ \\
\hline \multirow[t]{2}{*}{ Ownership $_{\mathrm{i}, \mathrm{t}}$} & $0.087^{* *}$ & $0.092^{* *}$ & 0.076 \\
\hline & $(0.068)$ & $(0.104)$ & $(0.002)$ \\
\hline \multirow[t]{2}{*}{$\mathrm{C}_{4}$} & $0.426^{* *}$ & $0.520^{* *}$ & $0.426^{* * *}$ \\
\hline & $(0.108)$ & $(0.131)$ & $(0.125)$ \\
\hline Regional controls & included & included & included \\
\hline \multirow[t]{2}{*}{ constant } & $-0.041 * *$ & $-0.010 * *$ & $-0.009 * *$ \\
\hline & $(0.003)$ & $(0.011)$ & $(0.008)$ \\
\hline Wald test & $6562.86^{* * *}$ & $866.59^{* * *}$ & $5866.47 * * *$ \\
\hline Sargan test ( $p$ value) & 0.101 & 0.382 & 0.108 \\
\hline $\operatorname{AR}(1)(p$ value $)$ & 0.000 & 0.000 & 0.000 \\
\hline AR (2) ( $p$ value) & 0.148 & 0.327 & 0.549 \\
\hline $\mathrm{N}$ firms & 11281 & 601 & 10879 \\
\hline $\mathrm{N}$ obs. & 52776 & 2462 & 50089 \\
\hline $\mathrm{R}^{2}$ & 0.31 & 0.32 & 0.36 \\
\hline
\end{tabular}

Note. Significance levels: $* 10 \% ; * * 5 \% ; * * * 1 \%$.

\section{Conclusions}

This research provides insight into an important issue concerning the relationship between financial channels and R\&D activity in Italian manufacturing firms over the 2006-2013 years.

The empirical evidence shows that the availability of external financing primarily affects the decision to engage in $R \& D$ activity rather than $R \& D$ intensity. Internal cash flow, on the contrary, does affect both the likelihood of whether firms will undertake any R\&D and the size of R\&D spending. The impact is strongly significant for financially weaker firms and SMEs, more sensitive to financial factors than large companies. Moreover, the econometric findings confirm the substantial role played by internal funding in R\&D activity performed by high-tech firms. Due to greater asymmetric information problems, small innovative firms mainly rely on cash-flow to finance innovative projects.

In summary, the overall evidence would confirm the pivotal role played by internal finance and, on the other side, the limited impact of bank loans and other forms of debt, not well suited for R\&D-intensive activities. Banks generally do not possess financial products and competencies to deal with investment in high-tech projects (especially by young innovative firms). Being Italy a bank-based economy, these results may contribute to explaining the causes for Italian low investment rate in innovative activity compared to other European countries. From a policy perspective, our study would contribute to the debate whether it might be socially desirable to offer tax incentives to SMEs in order to reduce the cost of capital they face for R\&D investment or to incentivize alternative small business financing options, like AIM-Italy (Mercato Alternativo del Capitale - MAC), still limited in Italy. Policymakers should establish framework conditions that foster innovative activity and promote new direct and indirect financing instruments - like corporate venturing, crowd funding, business angel, venture capital, grant, subsidies - to stimulate access to finance for R\&D and innovation, especially for small and medium enterprises. This would be beneficial for the country as a whole, given the relevance of small and 
medium sized firms in the Italian economy and their greater propensity to innovate in high-tech sectors.

\section{References}

Agostino, M., \& Trivieri, F. (2013). Does trade credit play a signaling role? Some evidence from SMEs microdata. Small Business Economics, 42, 131-151. http://dx.doi.org/10.1007/s11187-013-9478-8

Altomonte, C., \& Aquilante, T. (2012). The EU-EFIGE/Bruegel-Unicredit dataset. Bruegel Working Papers n.753, Bruegel.

Archibugi, D. (2001). Pavitt's taxonomy sixteen years on: A review article. Economics of Innovation and New Technology, 10, 415-425. http://dx.doi.org/10.1080/10438590100000016

Arellano, M., \& Bond, S. (1991). Some tests of specification for panel data: Monte Carlo evidence and an application to employment equations. The Review of Economic Studies, 58, 277-297. http://dx.doi.org/10.2307/2297968

Arora, A., Fosfuri, A., \& Gambardella, A. (2001). Markets for technology: The economics of innovation and corporate strategy. Cambridge, MA: MIT press.

Arrow, K. (1962). Economic Welfare and the Allocation of Resources for Invention. In R. Nelson (Ed.), The Rate and Direction of Inventive Activity: Economic and Social Factors (pp. 609-626). UMI.

Baumol, W. J. (2002). The Free-Market Innovation Machine: Analyzing the Growth Miracle of Capitalism. Princeton University Press.

Benfratello, L., Schiantarelli, F., \& Sembenelli, A. (2008). Banks and innovation: Microeconometric evidence on Italian firms. Journal of Financial Economics, 90, 197-217. http://dx.doi.org/10.1016/j.jfineco.2008.01.001

Berger, A., \& Udell, G. (1998). The economics of small business finance: The roles of private equity and debt markets in the financial growth cycle. Journal of Banking and Finance, 22, 613-673. http://dx.doi.org/10.1111/1468-0297.00682

Berger, A., \& Udell, G. (2002). Small business credit availability and relationship lending: The importance of bank organizational structure. The Economic Journal, 112, 32-53.

Bloch, C. (2005). R\&D investment and internal finance: the cash flow effect. Economics of Innovation and New Technology, 14, 213-223. http://dx.doi.org/10.1080/1043859042000312710

Blundell, R., \& Bond, S. (1998). Initial conditions and moment restrictions in dynamic panel data models. Journal of Econometrics, 87, 115-143. http://dx.doi.org/10.1016/S0304-4076(98)00009-8

Bond, S. R., \& Meghir, C. (1994). Dynamic Investment Models and the Firm's Financial Policy. Review of Economic Studies, 61, 197-222. http://dx.doi.org/10.2307/2297978

Bond, S., \& Van Reenen, J. (2007). Microeconometric Models of Investment and Employment. In James J. Heckman, \& Edward E. Leamer (Eds.), Handbook of Econometrics (pp. 4417-4498). North-Holland.

Bottazzi, L., \& Da Rin, M. (2002). Venture capital in Europe: Euro.nm and the financing of European innovative firms. Economic Policy, 34, 229-269. http://dx.doi.org/10.1111/1468-0327.00088

Bottazzi, L., Da Rin, M., \& Hellmann, T. (2008). Who are the active investors? Evidence from venture capital. Journal of Financial Economics, 89, 488-512. http://dx.doi.org/10.1016/j.jfineco.2007.09.003

Bougheas, S., Görg, H., \& Strobl, E. (2003). Is R\&D financially constrained? Theory and evidence from Irish $\begin{array}{lllll}\text { manufacturing. } & \text { Review of Industrial }\end{array}$ http://dx.doi.org/10.1023/A:1022905102446

Brown, J. R., \& Petersen, B. C. (2009). Why has the investment-cash flow sensitivity declined so sharply? Rising R\&D and equity market developments. Journal of Banking and Finance, 33, 971-984. http://dx.doi.org/10.1016/j.jbankfin.2008.10.009

Brown, J. R., \& Petersen, B. C. (2011). Cash holdings and R\&D smoothing. Journal of Corporate Finance, 17, 694-709. http://dx.doi.org/10.1016/j.jcorpfin.2010.01.003

Brown, J., Fazzari, S., \& Petersen, B. (2009). Financing innovation and growth: Cash flow, external equity, and the 1990s R\&D boom. Journal of Finance, 64, 151-186. http://dx.doi.org/10.1111/j.1540-6261.2008.01431.x

Bugamelli, M., Cannari, L., Lotti, F., \& Magri, S. (2012). Il gap innovativo del sistema produttivo italiano: Radici e possibili rimedi. Bank of Italy Occasional Papers n.121. Rome. 
Cameron, A. C., \& Trivedi, P. K. (2009). Microeconometrics Using Stata. Stata Press.

Carpenter, R. E., \& Petersen, B. C. (2002a). Is the growth of small firms constrained by internal finance? The Review of Economics and Statistics, 84, 298-309. http://dx.doi.org/10.1162/003465302317411541

Carpenter, R. E., \& Petersen, B. C. (2002b). Capital market imperfections, high-tech investment, and new equity financing. The Economic Journal, 112, 54-72. http://dx.doi.org/10.1111/1468-0297.00683

Cefis, E. (2003). Is there any persistence in innovative activities? International Journal of Industrial Organization, 21, 489-515. http://dx.doi.org/10.1016/S0167-7187(02)00090-5

Cefis, E., \& Orsenigo, L. (2001). The persistence of innovative activities. A cross-countries and cross-sectors comparative analysis. Research Policy, 30, 1139-1158. http://dx.doi.org/10.1016/S0048-7333(00)00139-6

Cleary, S., Povel, P., \& Raith, M. (2007). The U-Shaped Investment Curve: Theory and Evidence. Journal of Financial and Quantitative Analysis, 42, 1-39. http://dx.doi.org/10.1017/S0022109000002179

Czarnitzki, D., \& Hottenrott, H. (2011). R\&D investment and financing constraints of small and medium-sized firms. Small Business Economics, 36, 65-83. http://dx.doi.org/10.1007/s11187-009-9189-3

Danielson, M. G., \& Scott, J. A. (2004). Bank loan availability and trade credit demand. Financial Review, 39, 579-600. http://dx.doi.org/10.1111/j.0732-8516.2004.00089.x

De Blasio, G. (2005). Does trade credit substitute for bank credit? Evidence from firm level data. Economic Notes, 34, 85-112. http://dx.doi.org/10.1111/j.0391-5026.2005.00145.x

De Socio, A. (2010). La situazione economico-finanziaria delle imprese italiane nel confronto internazionale. Bank of Italy Occasional Papers n.66. Rome.

EIB. (2009). R\&D and the financing of innovation in Europe. EIB Papers n.14.

Encaoua, D., Laisney, F., Hall, B., \& Mairesse, J. (2000) The Economics and Econometrics of Innovation. Springer.

European Communities. (2002). A guide to financing innovation.

Geroski, P. A., Van Reenen, J., \& Walters, C. F. (1997). How persistently do firms innovate? Research Policy, 26 , 33-48. http://dx.doi.org/10.1016/S0048-7333(96)00903-1

Giannetti, C. (2012). Relationship lending and firm innovativeness. Journal of Empirical Finance, 19, 762-781. http://dx.doi.org/10.1016/j.jempfin.2012.08.005

Giudici, G., \& Paleari, S. (2000). The provision of finance to innovation: A survey conducted among Italian technology-based small firms. Small Business Economics, 14, 37-53. http://dx.doi.org/10.1023/A:1008187416389

Guariglia, A., \& Mateut, S. (2006). Credit channel, trade credit channel, and inventory investment: Evidence from a panel of UK firms. Journal of Banking and Finance, 30, 2835-2856. http://dx.doi.org/10.1016/j.jbankfin.2005.11.002

Guiso, L., Sapienza, P., \& Zingales, L. (2004). The Role Of Social Capital In Financial Development. American Economic Review, 94, 526-556. http://dx.doi.org/10.1257/0002828041464498

Hall, B. H. (1990). The impact of corporate restructuring on industrial research and development. Brookings Papers on Economic Activity, 1, 85-136. http://dx.doi.org/10.2307/2534781

Hall, B. H. (1992). Investment and research and development at the firm level: Does the source of financing matter? NBER Working Paper n.4096.

Hall, B. H. (2002). The financing of research and development. Oxford Review of Economic Policy, 18, 35-51. http://dx.doi.org/10.1093/oxrep/18.1.35

Hall, B. H. (2010). The financing of innovative firms. Review of Economics and Institutions, 1, 1-30. http://dx.doi.org/10.5202/rei.v1i1.4

Hall, B. H., \& Lerner, J. (2010). Financing R\&D and innovation. In B. Hall, \& N. Rosenberg (Eds.), The Handbook of the Economics of Innovation (pp. 610-638). Amsterdam: Elsevier.

Heckman, J. (1979). Sample selection bias as a specification error. Econometrica, 47, 153-161. http://dx.doi.org/10.2307/1912352

Himmelberg, C., \& Petersen, B. (1994). R\&D and internal finance: A panel study of small Firms in high-tech 
industries. The Review of Economics and Statistics, 76, 38-51. http://dx.doi.org/10.2307/2109824

Ichino, A., \& Maggi, G. (2000). Work Environment and Individual Background: Ex-plaining Regional Shirking Differentials in a Large Italian Firm. Quarterly Journal of Economics, 115, 1057-90. http://dx.doi.org/10.1162/003355300554890

Knack, S., \& Zack, P. (2001). Trust and Growth. Economic Journal, 111, 295-321. http://dx.doi.org/10.1111/1468-0297.00609

La Porta, R., Lopez de Silanes, F., Shleifer, A., \& Vishny, R. (1997). Legal Determinants of External Finance. Journal of Finance, 52, 1131-50. http://dx.doi.org/10.1111/j.1540-6261.1997.tb02727.x

Lerner, J. (1997). An empirical exploration of a technological race. The Rand Journal of Economics, 28, 228-247. http://dx.doi.org/10.2307/2555803

Love, I., Preve, L. A., \& Sarria-Allende, V. (2007). Trade credit and bank credit: Evidence from recent financial crises. Journal of Financial Economics, 83, 453-469. http://dx.doi.org/10.1016/j.jfineco.2005.11.002

Magri, S. (2009). The financing of small innovative firms: The Italian case. Economics of Innovation and New Technology, 18, 181-20. http://dx.doi.org/10.1080/10438590701738016

Marotta, G. (2005). When do trade credit discounts matter? Evidence from Italian firm-level data. Applied Economics, 37, 403-416. http://dx.doi.org/10.1080/0003684042000329063

Minetti, R., \& Zhu, S. C. (2011). Credit constraints and firm export: Microeconomic evidence from Italy. Journal of International Economics, 83, 109-125. http://dx.doi.org/10.1016/j.jinteco.2010.12.004

Myers, S. C. (1984). The capital structure puzzle. The Journal of Finance, 39, 574-592. http://dx.doi.org/10.1111/j.1540-6261.1984.tb03646.x

Myers, S. C., \& Majluf, N. S. (1984). Corporate financing and investment decisions when firms have information that investors do not have. Journal of Financial Economics, 13, 187-221. http://dx.doi.org/10.1016/0304-405X(84)90023-0

Nelson, R. (1959). The simple economics of basic scientific research. The Journal of Political Economy, 67, 297-306. http://dx.doi.org/10.1086/258177

Nilsen, J. (2002). Trade credit and the bank lending channel. Journal of Money, Credit and Banking, 34, 226-253. http://dx.doi.org/10.1353/mcb.2002.0032

Ogawa, K., Sterken, E., \& Tokutsu, I. (2013). The trade credit channel revisited: Evidence from micro data of Japanese small firms. Small Business Economics, 40, 101-118. http://dx.doi.org/10.1007/s11187-011-9344-5

Pederzoli, C., Thoma, G., \& Torricelli, C. (2013). Modelling credit risk for innovative SMEs: The role of innovation measures. Journal of Financial Services Research, 44, 111-129. http://dx.doi.org/10.1007/s10693-012-0152-0

Petersen, M. A., \& Rajan, R.G. (1997). Trade credit: Theories and evidence. Review of Financial Studies, 10, 661-691. http://dx.doi.org/10.1093/rfs/10.3.661

Savignac, F. (2008). Impact of financial constraints on innovation: What can be learned from a direct measure? $\begin{array}{llllll}\text { Economics of Innovation and New Technology, } & \text { 553-569. }\end{array}$ http://dx.doi.org/10.1080/10438590701538432

Schneider, C., \& Veugelers, R. (2010). On young highly innovative companies: Why they matter and how (not) to policy support them. Industrial and Corporate Change, 19, 969-1007. http://dx.doi.org/10.1093/icc/dtp052

Succurro, M. (2014). Intangible Assets Finance: A Complementary or Substitution Effect between External and Internal Channels? Evidence from the Italian Divide. International Journal of Economics and Finance, 6 , 1-14. http://dx.doi.org/10.5539/ijef.v6n12p1

Ughetto, E. (2007). The financing of innovative activities by banking institutions: policy issues and regulatory options. In B. Laperche, \& D. Uzunidis (Eds.), Powerful Finance and Innovation Trends in a High-Risk Economy (pp. 224-247). Palgrave Macmillan.

Ughetto, E. (2008). Does internal finance matter for R\&D? New evidence from a panel of Italian Firms. Cambridge Journal of Economics, 32, 907-925. http://dx.doi.org/10.1093/cje/ben015 
Vella, F., \& Verbeek, M. (1999). Estimating and Interpreting Models with Endogenous Treatment Effects. Journal of Business \& Economic Statistics, 17, 473-478.

\section{Notes}

Note 1. In the computation of external finance, we initially considered also external equity (defined as total common shareholders' equity less internal equity). However, data on external equity are substantially not available in the database for the analyzed sample of firms.

Note 2. In order to measure the size of a firm, different variables could be used like the number of employees, total assets and turnover. However, data on turnover are more reliable than those on total number of employees reported in the balance sheets, and there are less missing data. This is particularly true for small enterprises which represent a high percentage of our sample.

Note 3. When not available, we have used a measure of $R \& D$ expenditure obtained by applying three correction factors to each firm's accounting data on intangibles, as better explained in the methodological note reported in Supplementary material.

Note 4. The Heckman procedure assumes that an observation is censored if y has a missing value. We identify the censored observations by taking the log of $R \& D$.

Note 5 . We estimate the model by including both two lags of the dependent variable as regressors and two lags of the endogenous variable. The choice of the endogenous variables and the lags has been performed through the Difference-in-Sargan test. Consistent estimators have been obtained by using the specialized Stata commands xtabond and xtdpdsys.

\section{Copyrights}

Copyright for this article is retained by the author(s), with first publication rights granted to the journal.

This is an open-access article distributed under the terms and conditions of the Creative Commons Attribution license (http://creativecommons.org/licenses/by/3.0/). 